\title{
Potensi Interaksi Obat pada Pasien Skizofrenia di Salah Satu Rumah Sakit Jiwa di Provinsi Jawa Barat
}

\author{
Dwi A. Ramdini ${ }^{1}$, Sri A. Sumiwi ${ }^{2}$, Melisa I. Barliana ${ }^{3}$, Dika P. Destiani ${ }^{2}$, Ice L. Nur ${ }^{1}$ \\ ${ }^{1}$ Program Studi Magister Farmasi Klinik, Fakultas Farmasi, Universitas Padjadjaran, \\ Sumedang, Indonesia, ${ }^{2}$ Departemen Farmakologi dan Farmasi Klinik, Fakultas Farmasi, \\ Universitas Padjadjaran, Sumedang, Indonesia, ${ }^{3}$ Departemen Biologi Farmasi, \\ Fakultas Farmasi, Universitas Padjadjaran, Sumedang, Indonesia
}

\begin{abstract}
Abstrak
Antipsikotik merupakan terapi utama pada penyakit skizofrenia. Banyak di antara pasien skizofrenia menerima terapi kombinasi antipsikotik. Hal ini dapat menyebabkan kemungkinan timbulnya potensi interaksi obat. Studi ini bertujuan untuk mengevaluasi potensi interaksi obat dan mengidentifikasi faktorfaktor yang berpengaruh terhadap potensi interaksi obat. Studi potong lintang dan retrospektif dilakukan pada pasien skizofrenia periode tahun 2015-2016 di salah satu Rumah Sakit Jiwa di Provinsi Jawa Barat. Penelitian ini dilakukan dengan mengumpulkan data rekam medik pasien pada saat pasien menjalani rawat inap. Sebanyak $92,54 \%$ pasien teridentifikasi memiliki potensi interaksi obat dengan kategori significant $(78,24 \%)$, serious $(9,64 \%)$ dan minor (12,11\%). Potensi interaksi farmakodinamik ( $85 \%$ ) lebih mendominasi dibandingkan farmakokinetik (15\%). Hasil studi ini juga menyatakan sebanyak 35,16\% pasien tidak patuh dalam menjalani terapi dan 67,03\% memiliki komorbiditas berupa efek samping gejala ekstrapiramidal akibat antipsikotik. Analisis bivariat menunjukkan bahwa jumlah obat yang diresepkan, kepatuhan terapi dan komorbid (gejala ekstrapiramidal) berkaitan dengan potensi interaksi $(p<0,05)$. Hasil ini diperkuat oleh hasil analisis regresi logistik biner yang menunjukkan bahwa jumlah obat yang diresepkan $(\mathrm{OR}=14,139 ;(5,887-33,957) ; \mathrm{p}=0,000)$ dan kepatuhan $(\mathrm{OR}=2,424 ;(1,277-4,601)$; $\mathrm{p}=0,007)$ berhubungan signifikan terhadap potensi interaksi obat. Potensi kejadian interaksi obat pada pasien skizofrenia adalah sebesar $92,54 \%$ yang berkaitan dengan jumlah obat yang diberikan kepada pasien, dalam bentuk kombinasi terapi dan ketidakpatuhan pasien.
\end{abstract}

Kata kunci: Faktor potensi interaksi obat, interaksi obat potensial, skizofrenia

\section{Potential Drug Interactions on Schizophrenic Patients at a Mental Hospital in West Java, Indonesia}

\begin{abstract}
Antipsychotic is a primary therapy in schizophrenia. Many shizophrenic patients receive combination antipsychotic therapy which might lead to potential drug interactions. The aim of this study was to evaluate and identify factors associated with potential drug interactions. A cross-sectional and retrospective study was conducted on schizophrenic patients in the period of 2015-2016 at one of mental hospitals in the Province of West Java, Indonesia. This study used patients' medical record data when the patients were hospitalized. A total of $92,54 \%$ patients were identified as having potential drug interactions which categorized as significant (78.24\%), serious $(9.64 \%)$ and minor $(12.11 \%)$. Potential pharmacodynamic interaction $(85 \%)$ was more dominating than pharmacokinetic $(15 \%)$. It was also found that $35.16 \%$ of patients had poor therapeutic adherence and $67.03 \%$ had comorbidities in the form of extrapyramidal symptoms due to antipsychotics. Bivariate analysis showed that the adherence medication, comorbid (syndrome extrapyramidal), and the number of prescribed were related to the number of potential drugs interaction ( $p$-value $<0.05$ ). This result was strengthened by the result of logistic binary regression analysis which showed that the number of prescribed drugs $(\mathrm{OR}=14.139 ;(5.887-33.957) ; \mathrm{p}=0.000)$ and therapy adherence $(\mathrm{OR}=2.424 ;(1.277-4.601) ; \mathrm{p}=0.007)$ were significantly associated with potential drug interactions. The potential drug interaction in schizophrenic patient was $92.54 \%$ which related to a number of drugs taken by the patients in the form of combination therapy and patients' inadherence.
\end{abstract}

Keywords: Potential drug interaction, potential factors of drug interaction, schizophrenia

Korespondensi: Dwi A. Ramdini, M.Farm., Apt., Program Studi Magister Farmasi Klinik, Fakultas Farmasi, Universitas Padjadjaran, Sumedang, Jawa Barat 45363, Indonesia, email: dwiauliaramdhini@gmail.com

Naskah diterima: 15 Juli 2018, Diterima untuk diterbitkan: 10 November 2018, Diterbitkan: 1 Desember 2018 


\section{Pendahuluan}

Skizofrenia adalah gangguan jiwa kronis yang ditandai dengan adanya gejala positif dan negatif, serta gangguan afek. Antipsikotik merupakan terapi utama dalam mengatasi skizofrenia yang terdiri dari golongan generasi pertama/tipikal dan generasi kedua/atipikal. ${ }^{1}$ Keduanya merupakan penghambat reseptor dopamin dengan karakteristik yang berbeda. Berdasarkan pedoman terapinya, penggunaan antipsikotik atipikal tunggal pada pasien skizofrenia sangat direkomendasikan karena efek sindrom ekstrapiramidal yang minimal. ${ }^{2}$ Antipsikotik atipikal ini akan menghambat reseptor serotonin (5HT) dan dopamin (DA). Hal ini menyebabkan atipikal menimbulkan ekstrapiramidal lebih minimal dibandingkan dengan golongan tipikal. Strategi kombinasi antipsikotik marak digunakan, namun masih menjadi kontroversi di kalangan praktisi karena belum cukup bukti tentang efikasi dan keamanannya..$^{4-6}$

Terapi kombinasi antipsikotik seringkali menyebabkan terjadinya suatu interaksi obat. Interaksi obat adalah sebagai perubahan suatu efek farmakologi disebabkan penggunaannya bersamaan dengan obat lainnya. Penurunan efektivitas obat, peningkatan efek obat (toksik) hingga timbulnya reaksi obat yang merugikan merupakan dampak negatif dari interaksi obat. ${ }^{7}$ Berdasarkan mekanismenya, interaksi obat dibagi menjadi dua macam, yaitu interaksi farmakodinamik dan interaksi farmakokinetik. Interaksi farmakodinamik berkaitan dengan aksi obat pada tingkat reseptor yang dapat menyebabkan efek sinergis atau antagonis. Efek interaksi sinergisime antipsikotik dapat berupa mulut kering, pandangan kabur, dan kemungkinan timbulnya delirium. ${ }^{8}$ Salah satu efek berbahaya (serious) dari interaksi obat antipsikotik adalah pemanjangan corrected QT (QTc) interval. Interaksi ini dapat berisiko untuk menimbulkan torsade de pointe (TdP) atau gangguan irama jantung yang berakibat pada kematian mendadak akibat aritmia. ${ }^{9,10}$ Interaksi farmakokinetik antipsikotik pada umumnya disebabkan oleh adanya pengaruh pada metabolisme enzim sitokrom P450 (CYP450). Penggunaan quetiapin bersamaan dengan karbamazepin akan menyebabkan penurunan kadar plasma quetiapin disebabkan aktivitas isoenzim CYP3A4 yang meningkat. ${ }^{11}$ Hasil studi oleh Jain et al. melaporkan bahwa dari sebanyak 463 interaksi obat, 15,2\% di antaranya tergolong kategori severity major/ serious dan sebagian lainya adalah moderate/ significant. Berdasarkan onset terjadinya $6 \%$ di antaranya tergolong cepat (rapid), dan $81 \%$ ber-onset lambat (delayed). ${ }^{12}$

Potensi interaksi obat umum ditemukan pada pasien skizofrenia yang mendapatkan terapi kombinasi, yang merupakan kejadian drug related problem (DRPs) bagi pasien. ${ }^{13}$ Semakin banyak jumlah obatnya, risiko dari timbulnya potensi interaksi obat pun akan semakin meningkat pula. Kegiatan skrining dan monitoring potensi interaksi obat dapat mencegah terjadinya interaksi obat. Kejadian interaksi obat sangat berkaitan erat dengan risiko terjadinya peningkatan adverse drug reaction atau efek samping obat, ${ }^{14-16}$ yang dapat memengaruhi kepatuhan pasien. ${ }^{17-20}$ Salah satu efek samping yang membuat pasien tidak patuh dalam menjalankan pengobatan skizofrenia adalah gejala ekstrapiramidal. ${ }^{21}$ Pasien yang tidak patuh umumnya mendapat terapi kombinasi dan terapi tambahan untuk mengatasi efek samping yang muncul, dan akibatnya, jumlah pemakaian obat pun turut meningkat. Peningkatan jumlah obat yang diresepkan pada pasien dapat meningkatkan risiko terjadinya potensi interaksi obat. ${ }^{22-24}$ Tujuan studi ini adalah untuk mengetahui prevalensi dari potensi interaksi obat dan mengidentifikasi faktor yang berhubungan dengan interaksi obat yang terjadi pada pasien skizofrenia di salah satu rumah sakit jiwa di provinsi Jawa Barat. Studi ini akan membantu meningkatkan kesadaran pentingnya skrining 
dan monitoring penggunaan obat pada pasien skizofrenia.

\section{Metode}

Desain penelitian

Studi ini merupakan studi potong lintang dan retrospektif dengan menggunakan data rekam medik pasien skizofrenia rawat inap pada periode tahun 2015-2016 di salah satu Rumah Sakit Jiwa di Provinsi Jawa Barat, Indonesia. Kriteria inklusi penelitian ini adalah pasien usia $\geq 18$ tahun yang didiagnosis schizophrenia spetcrum disorder dengan terapi antipsikotik. Penelitian ini telah memperoleh persetujuan Komite Etik Penelitian Fakultas Kedokteran Universitas Padjadjaran Bandung dengan nomor 1127/UN6.C.10/PN/2017.

\section{Pengumpulan data}

Data yang diambil dari rekam medik pasien antara lain usia, jenis kelamin, kondisi medis, kepatuhan dan catatan pengobatan pasien. Kepatuhan dinilai dengan berdasarkan pada keterangan "putus obat", dilihat pada rekam medik sebelum pasien dirawat inap. Evaluasi potensi interaksi obat ini dilakukan dengan menggunakan tools drug interaction checker yang terdapat pada www.medscape.com. Interaksi obat yang dikaji pada penelitian ini yaitu antara obat antipsikotik dengan obat antipsikotik dan dengan obat nonantipsikotik, yaitu obat antikonvulsan, antikolinergik dan antidepresan. Potensi interaksi obat dinilai berdasarkan tingkat keparahannya (severity), mekanisme kerja dan potensi efek interaksi yang ditimbulkan. Tools ini mengkategorikan interaksi ke dalam empat macam, antara lain: (1) "contraindicated", yaitu kombinasi obat yang tidak pernah digunakan karena risiko tinggi interaksi berbahaya; (2) "serious-use alternative", potensi interaksi bersifat serius sehingga diperlukan pemantauan teratur oleh dokter, atau alternatif pengobatan lain; (3) "significant-monitor closely", kemungkinan interaksi menimbulkan akibat yang signifikan sehingga diperlukan pemantauan; dan (4) "minor", kemungkinan signifikansi interaksi kecil atau tidak signifikan. ${ }^{25,26}$

Analisis statistik

Studi ini menggunakan software SPSS versi ke-23. Data kontinu dihitung ke dalam mean \pm standar deviasi. Frekuensi dan persentase dihitung sebagai variabel kategori. Lalu, uji Kolmogorov-Smirnov dilakukan dengan tujuan mengevaluasi apakah variabel terdisitribusi normal atau tidak. Analisis bivariat digunakan untuk analisis korelasi hubungan karakteristik demografi terhadap potensi interaksi obat dan regresi logistik biner untuk mengetahui probabilitas faktor yang dianalisis.

\section{Hasil}

Berdasarkan profil penggunaan obat pada 295 pasien skizofrenia, sebanyak $67 \%$ pasien mendapat terapi kombinasi antipsikotik dan $33 \%$ terapi tunggal antipsikotik. Berdasarkan identifikasi potensi interaksi obat yang terjadi, sebanyak 273 pasien $(92,54 \%)$ memiliki potensi interaksi obat dan 22 pasien $(7,64 \%)$ tidak memiliki potensi interaksi obat. Berdasarkan mekanismenya, persentase potensi interaksi obat farmakodinamik adalah sebesar 85\%, sedangkan farmakokinetik $15 \%$, dengan total keseluruhan yaitu 1379 potensi interaksi obat (Gambar 1).

Jenis antipsikotik yang paling banyak diresepkan adalah haloperidol yakni sebesar $31,96 \%$, klozapin sebesar $21,50 \%$, risperidon $21,12 \%$, serta klorpromazin $14,95 \%$. Hal ini menyebabkan persentase obat-obat tersebut memiliki frekuensi interaksi obat yang lebih tinggi bila dibandingkan dengan antipsikotik yang lain, seperti trifluoperazin, olanzapin, quetiapin, aripirazol dan paliperidon seperti yang terlihat di Gambar 2. Potensi interaksi obat pasien skizofrenia yang telah berhasil diidentifikasi lalu dikategorikan berdasarkan 


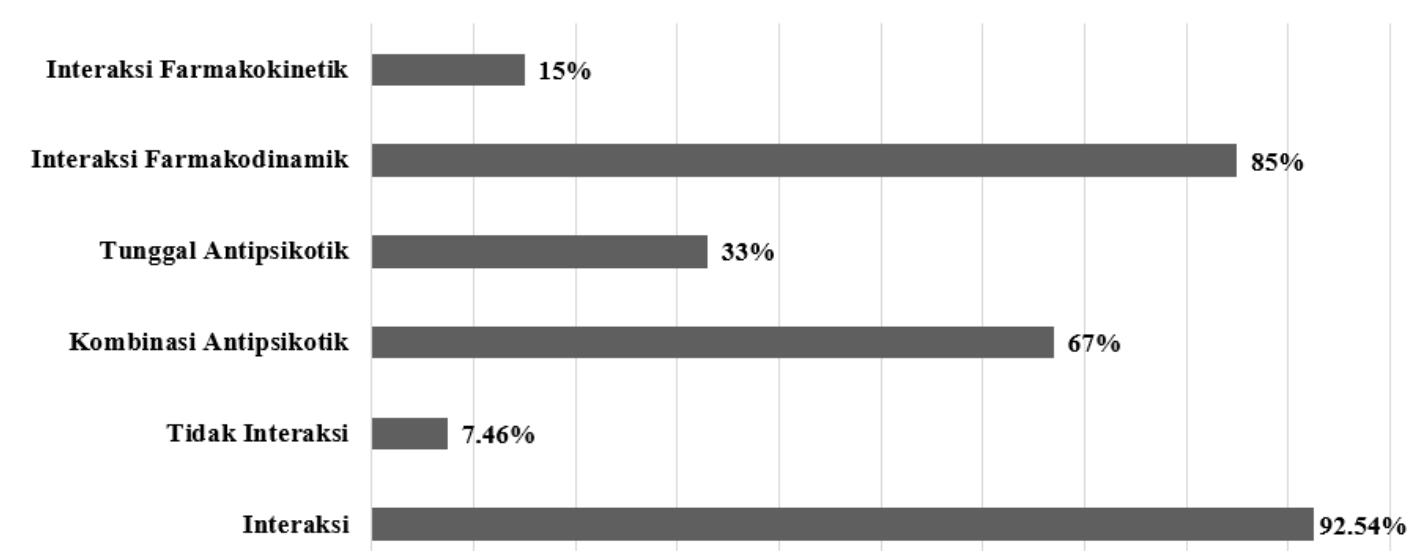

\section{Gambar 1 Profil Penggunaan Obat Antipsikotik dan Potensi Interaksi Obat pada Pasien Skizofrenia}

tingkat keparahannya. Presentase kategori tertinggi adalah significant $(78,24 \%)$, serious $(9,64)$ dan minor $(12,11 \%)$ (Gambar 3).

Potensi efek interaksi obat pada Tabel 1 menunjukkan efek potensial yang mungkin terjadi pada pasien skizofrenia. Frekuensi pada masing-masing pasangan potensi interaksi menunjukkan banyaknya potensi interaksi obat yang berisiko untuk muncul pada pasien skizofrenia. Pasangan interaksi obat dengan frekuensi tertinggi adalah haloperidol dengan klozapin ( $\mathrm{n}=187)$, diikuti klorpromazin dengan triheksifenidil $(n=134)$ dan klorpromazin dengan haloperidol $(\mathrm{n}=110)$.

Secara keseluruhan, efek potensial akibat interaksi obat yang paling dominan adalah sinergisme farmakodinamik. Efek potensial tersebut di antaranya gejala ekstrapiramidal dan sindroma neuroleptik maligna (SNM), pemanjangan QTc interval, dan peningkatan efek sedasi. Beberapa obat mempunyai mekanisme interaksi farmakodinamik dan farmakokinetik, seperti pada haloperidol dan klorpromazin. Secara farmakodinamik, keduanya sama-sama menghambat reseptor dopaminergik sehingga menimbulkan suatu efek sinergisme farmakodinamik, sedangkan secara farmakokinetik, haloperidol berperan sebagai inhibitor enzim CYP2D6 yang dapat meningkatkan kadar klorpromazin.

Potensi interaksi obat dengan mekanisme farmakokinetik ditunjukkan pada Tabel 2 . Mayoritas interaksi farmakokinetik adalah berupa pengaruh obat terhadap metabolisme

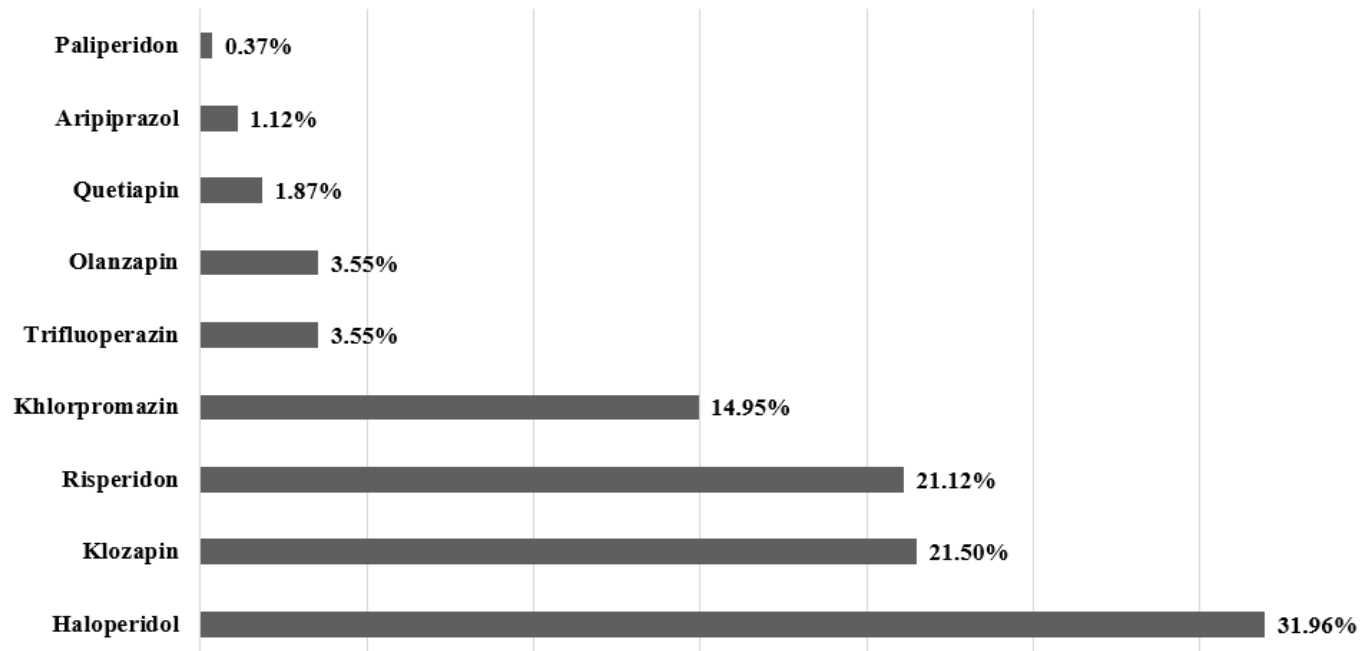

Gambar 2 Frekuensi Penggunaan Antipsikotik 


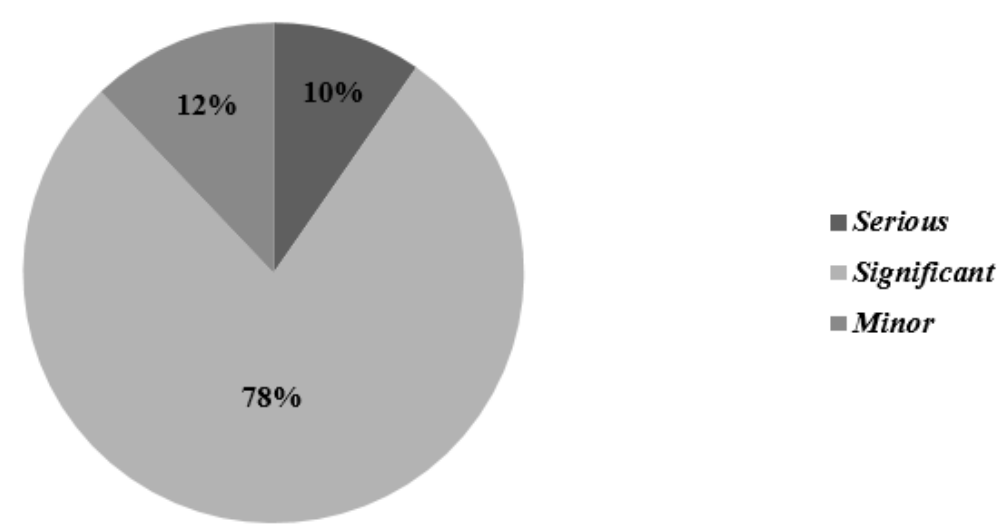

\section{Gambar 3 Kategori Potensi Interaksi Obat pada Pasien Skizofrenia}

isoenzim sitokrom P450 (CYP450). Obatobat seperti haloperidol, klobazam, fluoksetin sertralin dan asam valproat diketahui berperan sebagai inhibitor isoenzim CYP2D6. Obatobat ini mampu menghambat metabolisme obat-obat lain sehingga akan berpotensi dalam meningkatkan kadar obat antipsikotik.

Kejadian interaksi obat dapat dipicu oleh beberapa faktor, di antaranya adalah jumlah daru obat yang diresepkan, kepatuhan terapi, komorbiditas, serta jenis kelamin. Analisis hubungan faktor demografi dengan potensi interaksi obat dapat dilihat pada Tabel 3. Hasil analisis bivariat menunjukkan adanya hubungan yang signifikan antara kepatuhan dengan jumlah dari potensi interaksi obat $(\mathrm{p}=0,01)$. Variabel komorbid berupa gejala ekstrapiramidal $(p=0,00)$ dan jumlah obat yang diresepkan $(p=0,00)$ juga berhubungan siginifikan terhadap potensi interaksi obat. Variabel lainnya, seperti usia $(p=0,77)$ dan durasi penyakit $(p=0,71)$ tidak berhubungan signifikan terhadap potensi interaksi obat. Hasil ini diperkuat dengan hasil dari analisis regresi logistik biner yang menunjukkan bahwa, faktor jumlah obat yang diresepkan (Odds Ratio/OR=14,139; 95\% $\mathrm{CI}=5,887-33,957$; $\mathrm{p}=0,00)$ dan kepatuhan $(\mathrm{OR}=2,424 ; 95 \% \mathrm{CI}$ $1,277-4,601 ; p=0,007)$ berhubungan signifikan terhadap potensi interaksi obat, sedangkan jenis kelamin $(\mathrm{OR}=1,790$; 95\% CI 0,928$3,453 ; \mathrm{p}=0,082)$ dan komorbid $(\mathrm{OR}=1,013$; 95\% CI 0,427-2,407; $\mathrm{p}=0,976)$ tidak memiliki pengaruh yang signifikan terhadap potensi interaksi obat (Tabel 4).

\section{Pembahasan}

Hasil dari identifikasi potensi interaksi obat berdasarkan mekanismenya yang terbanyak adalah interaksi farmakodinamik (85\%) dengan tingkat keparahannya termasuk ke dalam kategori significant (78,24\%), sehingga diperlukan monitoring atau kajian yang lebih teliti untuk pemberian obat pada pasien di rumah sakit tersebut. Penelitian sebelumnya melaporkan bahwa kategori interaksi paling banyak adalah significant atau moderate. ${ }^{27}$ Efek potensi interaksinya antara lain gejala ekstrapiramidal, pemanjangan QTc interval dan sindrom neruroleptik malignan (SNM). SNM merupakan suatu reaksi idiosinkratik terhadap antipsikotik yang dapat mengancam jiwa dan ditandai dengan adanya demam, perubahan status mental, kekakuan otot, serta disfungsi autonom. ${ }^{28}$ Haloperidol, klozapin dan klorpromazin merupakan obat antipsikotik yang mempunyai efek samping gejala ekstrapiramidal, sehingga jika obatobat tersebut digunakan secara bersamaan akan meningkatkan risiko ekstrapiramidal. ${ }^{1,7}$ Gejala sindrom ekstrapiramidal antara lain distonia akut, postur abnormal dan kejang otot terutama pada wajah dan leher, akatsia, menjadi gelisah dan mondar-mandir, parkinson, tremor, kekakuan otot, dan bradikinesia. ${ }^{29}$ 
Tabel 1 Potensi Interaksi Farmakodinamik pada Pasien Skizofrenia

\begin{tabular}{|c|c|c|c|c|}
\hline \multicolumn{2}{|c|}{ Pasangan Interaksi Obat } & \multirow{2}{*}{$\frac{\text { Frekuensi }}{110}$} & \multirow{2}{*}{$\frac{\text { Kategori }}{\text { Serious }}$} & \multirow{2}{*}{$\begin{array}{r}\text { Potensi Efek Interaksi } \\
\text { Pemanjangan interval QTc }\end{array}$} \\
\hline Klorpromazin & Haloperidol & & & \\
\hline & & & Significant & $\begin{array}{l}\text { Meningkatkan efek antidopaminergik, gejala } \\
\text { ekstrapiramidal dan sindrom neuroleptik } \\
\text { maligna (SNM) }\end{array}$ \\
\hline & Triheksifenidil & 134 & Significant & $\begin{array}{l}\text { 1. Triheksifenidil menurunkan efek } \\
\text { klorpromazin melalui farmakodinamik } \\
\text { antagonisme }\end{array}$ \\
\hline & & & & $\begin{array}{l}\text { 2. Klorpromazin meningkatkan efek } \\
\text { triheksifenidil melalui sinergisme ‘ } \\
\text { farmakodinamik }\end{array}$ \\
\hline & Risperidon & 69 & Significant & 1. Pemanjangan QTc interval \\
\hline & & & & $\begin{array}{l}\text { 2. Meningkatkan efek antidopaminergik } \\
\text { termasuk gejala ekstrapiramidal dan SNM }\end{array}$ \\
\hline & & & & 3. Meningkatkan efek sedasi \\
\hline & Klozapin & 10 & Significant & $\begin{array}{l}\text { 1. Meningkatkan efek antidopaminergik } \\
\text { termasuk gejala ekstrapiramidal dan SNM }\end{array}$ \\
\hline & & & & 2. Meningkatkan efek sedasi \\
\hline & Lorazepam & 3 & Significant & Meningkatkan efek sedasi \\
\hline & Amitriptilin & 2 & Serious & Pemanjangan interval QTc \\
\hline & & & Significant & Meningkatkan efek sedasi \\
\hline & & & Minor & $\begin{array}{l}\text { Efek sinergisme farmakodinamik } \\
\text { (penambahan efek antikolinergik) }\end{array}$ \\
\hline \multirow[t]{10}{*}{ Haloperidol } & Klozapin & 187 & Significant & $\begin{array}{l}\text { 1. Meningkatkan efek antidopaminergik } \\
\text { termasuk gejala ekstrapiramidal dan SNM }\end{array}$ \\
\hline & & & & 2. Meningkatkan efek sedasi \\
\hline & & & & 3. Pemanjangan interval QTc \\
\hline & Triheksifenidil & 108 & Significant & $\begin{array}{l}\text { Haloperidol meningkatkan efek } \\
\text { triheksifenidil melalui sinergisme } \\
\text { farmakodinamik }\end{array}$ \\
\hline & Risperidon & 40 & Significant & 1. Pemanjangan interval QTc \\
\hline & & & & $\begin{array}{l}\text { 2. Meningkatkan efek antidopaminergik } \\
\text { termasuk gejala ekstrapiramidal dan SNM }\end{array}$ \\
\hline & & & & 3. Meningkatkan efek sedasi \\
\hline & Lorazepam & 16 & Significant & Meningkatkan efek sedasi \\
\hline & Amitriptilin & 1 & Serious & Pemanjangan interval QTc \\
\hline & & & Significant & Meningkatkan efek sedasi \\
\hline \multirow[t]{5}{*}{ Klozapin } & Triheksifenidil & 69 & Significant & $\begin{array}{l}\text { Efek sinergisme farmakodinamik } \\
\text { (penambahan efek antikolinergik) }\end{array}$ \\
\hline & Risperidon & 68 & Significant & $\begin{array}{l}\text { 1. Meningkatkan efek antidopaminergik, } \\
\text { gejala ekstrapiramidal dan SNM. }\end{array}$ \\
\hline & & & & 2. Meningkatkan efek sedasi \\
\hline & Olanzapin & 1 & Significant & $\begin{array}{l}\text { 1. Meningkatkan efek antidopaminergik, } \\
\text { gejala ekstrapiramidal dan SNM. }\end{array}$ \\
\hline & & & & 2. Meningkatkan efek sedasi \\
\hline Risperidon & Triheksifenidil & 60 & Significant & $\begin{array}{l}\text { Efek sinergisme farmakodinamik } \\
\text { (penambahan efek antikolinergik) }\end{array}$ \\
\hline
\end{tabular}


Tabel 1 Potensi Interaksi Farmakodinamik pada Pasien Skizofrenia (Lanjutan)

\begin{tabular}{|c|c|c|c|c|}
\hline \multicolumn{2}{|c|}{ Pasangan Interaksi Obat } & \multirow{2}{*}{$\frac{\text { Frekuensi }}{37}$} & \multirow{2}{*}{$\begin{array}{r}\text { Kategori } \\
\text { Significant }\end{array}$} & \multirow{2}{*}{$\begin{array}{r}\text { Potensi Efek Interaksi } \\
\text { Meningkatkan efek sedasi }\end{array}$} \\
\hline Risperidon & Lorazepam & & & \\
\hline & Amitriptilin & 8 & Significant & Meningkatkan efek sedasi \\
\hline & Diazepam & 1 & Significant & Meningkatkan efek sedasi \\
\hline & Maprotilin & 2 & Significant & 1. Pemanjangan interval QTc \\
\hline & & & & 2. Meningkatkan efek sedasi \\
\hline \multirow[t]{11}{*}{ Quetiapin } & Haloperidol & 8 & Significant & $\begin{array}{l}\text { 1. Meningkatkan efek antidopaminergik } \\
\text { termasuk gejala ekstrapiramidal dan SNM }\end{array}$ \\
\hline & & & & 2. Meningkatkan efek sedasi \\
\hline & Triheksifenidil & 7 & Significant & $\begin{array}{l}\text { Efek sinergisme farmakodinamik (penambahan } \\
\text { efek antikolinergik) }\end{array}$ \\
\hline & Klorpromazin & 3 & Significant & $\begin{array}{l}\text { 1. Meningkatkan efek antidopaminergik } \\
\text { termasuk gejala ekstrapiramidal dan SNM }\end{array}$ \\
\hline & & & & 2. Meningkatkan efek sedasi \\
\hline & Trifluoperazin & 2 & Significant & $\begin{array}{l}\text { 1. Meningkatkan efek antidopaminergik } \\
\text { termasuk gejala ekstrapiramidal dan SNM }\end{array}$ \\
\hline & & & & 2. Meningkatkan efek sedasi \\
\hline & Klozapin & 1 & Significant & $\begin{array}{l}\text { 1. Meningkatkan efek antidopaminergik } \\
\text { termasuk gejala ekstrapiramidal dan SNM }\end{array}$ \\
\hline & & & & 2. Meningkatkan efek sedasi \\
\hline & Klobazam & 1 & Significant & Meningkatkan sedasi atau depresi pernapasan \\
\hline & Lorazepam & 1 & Significant & Meningkatkan efek sedasi \\
\hline \multirow[t]{11}{*}{ Olanzapin } & Haloperidol & 10 & Significant & $\begin{array}{l}\text { 1. Meningkatkan efek antidopaminergik } \\
\text { termasuk gejala ekstrapiramidal dan SNM }\end{array}$ \\
\hline & & & & 2. Meningkatkan efek sedasi \\
\hline & & & & 3. Pemanjangan interval QTc \\
\hline & Klorpromazin & 8 & Significant & $\begin{array}{l}\text { 1. Meningkatkan efek antidopaminergik } \\
\text { termasuk gejala ekstrapiramidal dan SNM }\end{array}$ \\
\hline & & & & 2. Meningkatkan efek sedasi \\
\hline & Risperidon & 6 & Significant & $\begin{array}{l}\text { 1. Meningkatkan efek antidopaminergik } \\
\text { termasuk gejala ekstrapiramidal dan SNM }\end{array}$ \\
\hline & & & & 2. Meningkatkan efek sedasi \\
\hline & Triheksifenidil & 5 & Significant & $\begin{array}{l}\text { Efek sinergisme farmakodinamik (penambahan } \\
\text { efek antikolinergik) }\end{array}$ \\
\hline & Lorazepam & 2 & Significant & Meningkatkan efek sedasi \\
\hline & Klozapin & 2 & Significant & $\begin{array}{l}\text { 1. Meningkatkan efek antidopaminergik } \\
\text { termasuk gejala ekstrapiramidal dan SNM }\end{array}$ \\
\hline & & & & 2. Meningkatkan efek sedasi \\
\hline \multirow[t]{5}{*}{ Paliperidon } & Klorpromazin & 4 & Significant & $\begin{array}{l}\text { 1. Meningkatkan efek antidopaminergik } \\
\text { termasuk gejala ekstrapiramidal dan SNM }\end{array}$ \\
\hline & & & & 2. Meningkatkan efek sedasi \\
\hline & Risperidon & 3 & Significant & $\begin{array}{l}\text { 1. Meningkatkan efek antidopaminergik } \\
\text { termasuk gejala ekstrapiramidal dan SNM }\end{array}$ \\
\hline & & & & 2. Meningkatkan efek sedasi \\
\hline & & & & 3. Pemanjangan interval QTc \\
\hline
\end{tabular}


Tabel 1 Potensi Interaksi Farmakodinamik pada Pasien Skizofrenia (Lanjutan)

\begin{tabular}{|c|c|c|c|c|}
\hline \multicolumn{2}{|c|}{ Pasangan Interaksi Obat } & \multirow{3}{*}{$\frac{\text { Frekuensi }}{1}$} & \multirow{3}{*}{$\frac{\text { Kategori }}{\text { Significant }}$} & \multirow{3}{*}{$\begin{array}{l}\text { Potensi Efek Interaksi } \\
\text { 1. Meningkatkan efek antidopaminergik } \\
\text { termasuk gejala ekstrapiramidal dan SNM } \\
\text { 2. Meningkatkan efek sedasi }\end{array}$} \\
\hline Paliperidon & Olanzapin & & & \\
\hline & & & & \\
\hline & Klobazam & 1 & Significant & Meningkatkan sedasi atau depresi pernapasan \\
\hline \multirow[t]{13}{*}{ Trifluoperazin } & Triheksifenidil & 26 & Significant & $\begin{array}{l}\text { Triheksifenidil menurunkan efek } \\
\text { trifluoperazin dan meningkatkan efek } \\
\text { triheksifenisil }\end{array}$ \\
\hline & Risperidon & 5 & Significant & $\begin{array}{l}\text { 1. Meningkatkan efek antidopaminergik } \\
\text { termasuk gejala ekstrapiramidal dan SNM }\end{array}$ \\
\hline & & & & 2. Meningkatkan efek sedasi \\
\hline & & & & 3. Pemanjangan interval QTc \\
\hline & Klorpromazin & 6 & Serious & Pemanjangan interval QTc \\
\hline & & 6 & Significant & $\begin{array}{l}\text { 1. Meningkatkan efek antidopaminergik } \\
\text { termasuk gejala ekstrapiramidal dan SNM }\end{array}$ \\
\hline & & & & 2. Meningkatkan efek sedasi \\
\hline & Amitriptilin & 2 & Serious & Pemanjangan interval QTc \\
\hline & & & Significant & Meningkatkan efek sedasi \\
\hline & Lorazepam & 2 & Significant & Meningkatkan efek sedasi \\
\hline & Haloperidol & 2 & Significant & $\begin{array}{l}\text { 1. Meningkatkan efek antidopaminergik } \\
\text { termasuk gejala ekstrapiramidal dan SNM }\end{array}$ \\
\hline & & & & 2. Meningkatkan efek sedasi \\
\hline & & & & 3. Pemanjangan interval QTc \\
\hline Trifluoperazin & Olanzapin & 2 & Significant & $\begin{array}{l}\text { 1. Meningkatkan efek antidopaminergik } \\
\text { termasuk gejala ekstrapiramidal dan SNM }\end{array}$ \\
\hline & & & & 2. Meningkatkan efek sedasi \\
\hline \multirow[t]{2}{*}{ Aripiprazol } & Risperidon & 4 & Significant & $\begin{array}{l}\text { 1. Meningkatkan efek antidopaminergik } \\
\text { termasuk gejala ekstrapiramidal dan } \\
\text { SNM }\end{array}$ \\
\hline & & & & 2. Meningkatkan efek sedasi \\
\hline Donepezil & Triheksifenidil & 2 & Significant & Penurunan efek triheksifenidil \\
\hline Amitriptilin & Lorazepam & 3 & Significant & Meningkatkan efek sedasi \\
\hline \multirow[t]{5}{*}{ Triheksifenidil } & Amitriptilin & 4 & Significant & Penambahan efek antikolinergik \\
\hline & Maprotilin & 1 & Serious & 1. Meningkatkan QTc interval \\
\hline & & & & 2. Meningkatkan kadar serotonin \\
\hline & & & Significant & 1. Penambahan efek antikolinergik \\
\hline & & & & 2. Meningkatkan efek sedasi \\
\hline
\end{tabular}

Pasien yang mengalami gejala ekstrapiramidal akan diberikan suatu terapi tambahan yaitu pemberian triheksifenidil untuk mengatasi gejala ekstrapiramidal akibat antipsikotik. ${ }^{1}$

Studi oleh Elliot et al. menyatakan bahwa dari 65 pasien skizofrenia, $6 \%$ di antaranya mengalami pemanjangan QTc interval, ${ }^{30}$ yang merupakan suatu gangguan irama jantung terkait dengan repolarisasi dan depolarisasi jantung. ${ }^{31}$ Semua obat antipsikotik dapat berkontribusi pada pemanjangan repolarisasi ventrikel (pemanjangan QTc interval) ini, 
Tabel 2 Potensi Interaksi Farmakokinetik pada Pasien Skizofrenia

\begin{tabular}{llcll}
\hline \multicolumn{1}{c}{ Pasangan Interaksi Obat } & Frekuensi & Kategori & \multicolumn{1}{c}{ Potensi Efek Interaksi } \\
\hline Haloperidol & Klorpromazin & 110 & Minor & Kadar klorpromazin akan meningkat \\
Klobazitor $)$ & Risperidon & 40 & Minor & Kadar risperidon akan meningkat \\
(Inhibitor-kuat) & Klorpromazin & 5 & Significant & Kadar klorpromazin akan meningkat \\
Fluoksetin & Risperidon & 4 & Significant & Kadar atau efek risperidon akan meningkat \\
(Inhibitor-kuat) & Klorpromazin & 7 & Serious & Kadar klorpromazin akan meningkat \\
& Klozapin & 8 & Significant & Kadar klozapin akan meningkat \\
& Risperidon & 4 & Serious & Kadar risperidon akan meningkat \\
Sertralin & Risperidon & 4 & Significant & Kadar risperidon akan meningkat \\
(Inhibitor-kuat) & Haloperidol & 4 & Significant & Kadar haloperidol akan meningkat \\
& Klozapin & 3 & Significant & Kadar klozapin akan meningkat \\
& Trifluoperazin & 1 & Significant & Kadar trifluoperazin akan meningkat \\
& Klozapin & 13 & Minor & Kadar klozapin menurun (protein binding \\
Asam valproat & & & competitive) \\
& Amitriptilin & 2 & Minor & Peningkatan kadar keduanya akibat \\
Klorpromazin & penghambatan metabolisme \\
\hline
\end{tabular}

yang kemudian dapat mengakibatkan TdP. Polimorfik takikardia ventrikel atau TdP berisiko menyebabkan fibrilasi ventrikel dan kematian mendadak. ${ }^{32,33}$ Hasil beberapa studi melaporkan bahwa kejadian pemanjangan QTc interval pada terapi tunggal antipsikotik dan kombinasi memiliki potensi yang sama dan risiko timbulnya QTc interval ini perlu dilakukan monitoring. ${ }^{34-36}$

Jumlah potensi interaksi farmakokinetik (15\%) lebih sedikit jika dibandingkan dengan interaksi farmakodinamik. Potensi interaksi farmakokinetik ini banyak ditemukan pada penggunaan sertralin, klobazam fluoksetin

Tabel 3 Analisis Bivariat Faktor Demografi Pasien terhadap Potensi Interaksi Obat

\begin{tabular}{|c|c|c|c|}
\hline \multicolumn{2}{|c|}{ Karakteristik } & $\begin{array}{c}\text { Frekuensi }(\%) \\
(n=273)\end{array}$ & \multirow{3}{*}{$\begin{array}{r}\text { Nilai p } \\
0,66\end{array}$} \\
\hline Jenis kelamin & Perempuan & $87 \quad(31,87)$ & \\
\hline & Laki-laki & $186(68,13)$ & \\
\hline \multirow[t]{4}{*}{ Usia (tahun) } & $20-29$ & $83 \quad(30,40)$ & \multirow{4}{*}{0,77} \\
\hline & $30-39$ & $92 \quad(33,70)$ & \\
\hline & $40-49$ & $61 \quad(22,34)$ & \\
\hline & $50-59$ & $37(13,56)$ & \\
\hline \multirow[t]{2}{*}{ Kepatuhan } & Ya & $177 \quad(64,80)$ & \multirow[t]{2}{*}{$0,01 *$} \\
\hline & Tidak & $96 \quad(35,20)$ & \\
\hline Komorbid & Ya & $183(67,03)$ & $0,00 *$ \\
\hline Ekstrapiramidal & Tidak & $90 \quad(32,96)$ & \multirow{3}{*}{$0,00 *$} \\
\hline \multirow[t]{2}{*}{ Jumlah peresepan obat } & $\leq 2$ & $80 \quad(29,30)$ & \\
\hline & $\geq 3$ & $193(70,70)$ & \\
\hline \multirow[t]{3}{*}{ Durasi penyakit (tahun) } & $1-10$ & $172(63,00)$ & \multirow{3}{*}{0,71} \\
\hline & $11-20$ & $86 \quad(31,50)$ & \\
\hline & $21-30$ & $13 \quad(4,80)$ & \\
\hline
\end{tabular}


Tabel 4 Analisis Regresi Logistik Biner Faktor-Faktor yang Berhubungan dengan Potensi Interaksi Obat

\begin{tabular}{|c|c|c|c|c|c|}
\hline \multirow{2}{*}{ Variabel } & & \multicolumn{2}{|c|}{ Potensi Interaksi Obat $(\mathrm{n}=295)$} & \multirow{2}{*}{ Nilai p } & \multirow{2}{*}{ OR $(95 \%$ CI $)$} \\
\hline & & Tidak & Ya & & \\
\hline \multirow[t]{2}{*}{ Jenis Kelamin } & Perempuan & 11 & 87 & 0,082 & $1,790(0,928-3,453)$ \\
\hline & Laki-laki & 11 & 186 & & \\
\hline \multirow[t]{2}{*}{ Kepatuhan } & Tidak & 8 & 96 & $0,007 *$ & $2,424(1,277-4,601)$ \\
\hline & $\mathrm{Ya}$ & 14 & 177 & & \\
\hline \multirow[t]{2}{*}{ Komorbid ekstrapiramidal } & Tidak & 19 & 90 & 0,976 & $1,013(0,427-2,407)$ \\
\hline & Ya & 3 & 183 & & \\
\hline \multirow[t]{2}{*}{ Jumlah obat } & $\leq 2$ & 13 & 80 & $0,000^{*}$ & $14,139(5,887-33,957)$ \\
\hline & $\geq 3$ & 9 & 193 & & \\
\hline
\end{tabular}

*signifikan $(\mathrm{p}<0,05), \mathrm{OR}=$ Odds Ratio

dan haloperidol yang diketahui berperan sebagai inhibitor isoenzim CYP2D6. Obatobat ini akan menghambat isoenzim CYP2D6 yang bertanggung jawab dalam metabolisme obat antipsikotik. Dampak dari penghambatan ini adalah terjadi peningkatan kadar obat antipsikotik, sehingga berpotensi meningkat efek farmakologi dan efek samping obat. ${ }^{8,37}$ Gejala ekstrapiramidal berat banyak terjadi pada pasien yang menggunakan kombinasi dari antipsikotik dengan fluoksetin, yang disebabkan penghambatan enzim CYP2D6 oleh fluoksetin. ${ }^{36}$

Hasil studi ini juga menemukan adanya potensi pada peningkatan efek antikolinergik $(n=371)$. Potensi interaksi ini terdeteksi pada penggunaan dari obat triheksifenidil bersama dengan klorpromazin, haloperidol, klozapin serta risperidon. Meskipun pemberian dari triheksifenidil dimaksudkan untuk mengatasi gejala ekstrapiramidal akibat antipsikotik, namun secara farmakologi, obat ini dapat memberikan efek sinergisme. Mulut kering, pandangan kabur, dan delirium merupakan potensi efek interaksinya. ${ }^{8}$ Hasil sebuah studi melaporkan adanya kejadian paralytic ileus dengan impaksi fekal pada 6 pasien yang menggunakan kombinasi dari triheksifenidil dan klorpromazin. Mekanisme kejadian ini disebabkan oleh aksi antagonis reseptor kolinergik di saluran cerna yang berperan dalam motilitas usus. ${ }^{38}$ Kombinasi obat ini juga dapat menimbulkan berkurangnya efek klorpromazin, ${ }^{39}$ akibat aktivitas antagonisme dari reseptor kolinergik dan muskarinik oleh triheksifenidil di area otak dan jaringan perifer. $^{40}$

Berdasarkan hasil dari uji analisis bivariat dan uji regresi logistik, jenis kelamin tidak berhubungan signifikan terhadap potensi interaksi obat $(\mathrm{p}=0,082)$ dengan nilai $\mathrm{OR}=$ 1,790 (95\% CI 0,928-3,453). Pada penelitian ini, diketahui pasien yang tidak patuh terhadap pengobatannya yaitu sebanyak $35,16 \%$ dari total 295 pasien. Salah satu penyebabnya adalah timbulnya efek samping antipsikotik seperti gejala ekstrapiramidal, oleh karena itu diperlukan terapi tambahan untuk mengatasi efek samping tersebut. ${ }^{23,24}$ Analisis bivariat menunjukkan bahwa faktor kepatuhan terapi berhubungan signifikan terhadap potensi interaksi $(p=0,01)$, hasil ini diperkuat oleh hasil analisis regresi logistik biner $(\mathrm{p}=0,007)$ dengan nilai OR 2,424 (95\% CI 1,277$4,601)$ yang berarti bahwa pasien tidak patuh lebih berisiko mengalami potensi interaksi 2,424 kali lebih besar dibandingkan pasien yang patuh.

Pada penelitian ini juga dianalisis pengaruh dari komorbid berupa efek samping gejala ekstrapiramidal terhadap potensi interaksi. Diperoleh bahwa $67,03 \%$ pasien mengalami komorbiditas berupa gejala ekstrapiramidal akibat dari antipsikotik kombinasi. Gejala 
ekstrapiramidal ini diatasi dengan memberikan triheksifenidil. Studi terdahulu menyatakan bahwa komorbid merupakan suatu prediktor potensi interaksi obat. ${ }^{1}$ Hasil dari analisis bivariat menyatakan bahwa faktor komorbid gejala ekstrapiramidal berhubungan secara signifikan terhadap potensi interaksi $(p=0,00)$. Hasil analisis regresi logistik menunjukkan bahwa komorbid dan potensi interaksi obat tidak berhubungan secara signifikan $(\mathrm{p}=0,976$; $\mathrm{OR}=1,013 ; 95 \% \mathrm{CI}:$ 0,427-2,407), meskipun demikian, berdasarkan nilai OR, pasien dengan komorbid gejala ekstrapiramidal memiliki risiko 1,013 kali lebih tinggi untuk mengalami potensi interaksi obat.

Jumlah obat yang diresepkan berhubungan signifikan terhadap potensi interaksi $(p=0,00)$. Berdasarkan hasil analisis regresi logistik, jumlah obat yang diresepkan berhubungan signifikan terhadap potensi interaksi obat $(\mathrm{p}=0,00)$ dengan nilai OR 14,139 (95\% CI $5,887-33,957)$. Pasien yang menerima jumlah obat $\geq 3$ memiliki risiko 14,139 kali lebih besar dalam mengalami potensi interaksi obat dibandingkan pasien yang mendapat $\leq 2$ obat. Studi terdahulu melaporkan bahwa jumlah peresepan obat secara signifikan memiliki pengaruh terhadap potensi interaksi obat. ${ }^{41}$ Berdasarkan penggunaan antipsikotik, sebanyak $65,4 \%$ pasien skizofrenia yang mendapat antipsikotik kombinasi terdeteksi memiliki potensi interaksi dan sebanyak 27,1\% adalah pasien yang mendapat antipsikotik tunggal dengan kombinasi nonantipsikotik, hal ini sejalan dengan maraknya penggunaan dari obat antipsikotik kombinasi pada pasien skizofrenia di dalam praktik klinis. ${ }^{4,42}$ Tidak tercapai atau kurangnya respon terapi tunggal menjadi alasan diberikanya terapi tersebut. ${ }^{6}$ Penggunaan terapi kombinasi harus disertai monitoring ketat dan pertimbangan apakah manfaatnya lebih besar dibandingkan risiko buruk yang ditimbulkan. ${ }^{43}$

Potensi interaksi obat yang mengancam jiwa memang jarang terjadi dan ditemukan, namun pengaruh respon obat dan kejadian reaksi merugikan merupakan dampak klinis yang signifikan. Pasien skizofrenia berisiko tinggi mengalami potensi interaksi obat karena durasi pengobatan yang lama serta jumlah terapi obat yang dikonsumsi. Kesadaran serta pengetahuan mengenai potensi interaksi obat harus menjadi perhatian khusus bagi dokter dan farmasis. Hal ini penting dilakukan untuk mengurangi risiko terjadinya potensi interaksi obat yang muncul. Monitoring terhadap potensi interaksi sangat penting dilakukan agar efek yang membahayakan tidak terjadi. Studi ini memiliki limitasi, di antaranya digunakannya teknik sampling yang sederhana sehingga membatasi ekstrapolasi hasil yang diperoleh. Peneliti menilai potensi interaksi berdasarkan pendekatan tools drug interaction checker, sehingga interaksi obat ini bersifat teoritis bukan faktual. Data yang digunakan adalah data sekunder rekam medik pasien dengan informasi yang cukup terbatas, oleh karena itu perlu dilakukan investigasi secara prospektif. Penelitian ini diharapkan dapat memberikan gambaran tentang potensi kejadian interaksi obat pada pasien skizofrenia, sekaligus menjadi langkah awal untuk penelitian selanjutnya.

\section{Simpulan}

Berdasarkan hasil penelitian ini, didapatkan prevalensi potensi kejadian interaksi obat pada pasien skizofrenia sebesar 92,54\% dengan mayoritas masuk ke dalam kategori interaksi significant (78,24\%). Tingginya persentase ini disebabkan banyaknya jumlah obat yang diresepkan pada pasien skizofrenia. Penggunaan obat-obatan selain antipsikotik, antara lain antikolinergik, antikonvulsan dan antidepresan juga banyak diberikan pada pasien skizofrenia. Jumlah obat yang diresepkan dan kepatuhan terapi berhubungan signifikan dengan potensi interaksi obat. Oleh karena itu, monitoring respon obat pada pasien skizofrenia harus dilakukan dengan baik untuk mengurangi 
interaksi obat dan risiko efek samping yang mungkin terjadi.

\section{Pendanaan}

Penelitian ini dilaksanakan tanpa memperoleh bantuan dana dari sumber manapun.

\section{Konflik Kepentingan}

Seluruh penulis menyatakan tidak terdapat potensi konflik kepentingan dengan penelitian, kepenulisan (authorship), dan atau publikasi artikel ini.

\section{Daftar Pustaka}

1. Stahl SM. Essential pharmacology neuroscientific basis and practical application, $4^{\text {th }}$ ed. Cambridge: Cambridge University Press; 2013.

2. DiPiro, Joseph T. Pharmacotherapy: A pathophysiologic approach. New York: McGraw-Hill Medical; 2008.

3. Meltzer HY. Update on typical and atypical antipsichotic drugs. Annu Rev Med. 2013;64:393-406. doi: 10.1146/ann urev-med-050911-161504.

4. Lochman van Bennekom MW, Gijsman $\mathrm{H}$, Zitman FG. Antipsychotic polypharmacy in psychotic disorder: A critical review of neurobiology, efficacy, tolerability and cost effectiveness. J Psychopharmacol. 2013;27(4):327-36. doi: 10.1177/026988 1113477709 .

5. Taylor DM, Smith L. Augmentation of clozapine with a second antipsychotic a meta-analysis of randomized plaebo controlled studies. Acta Psychiatr Scand. 2009;119(6):419-25. doi:10.1111/j.16000447.2009.01367.x.

6. Barnes TR, Paton C. Antipsychotic polypharmacy in schizophrenia: Benefits and risk. CNS Drug. 2011;25(5):383-99. doi: 10.2165/11587810-000000000-00000
7. Bleakley S. Identifying and reducing the risk of antipsychotic drug interactions. Prog Neurol Psychiatr. 2012;16(2):20-4. doi: 10.1002/pnp.231

8. Mora F, Molina JD, Zubillaga E, LopezMunoz F, Alamo C. CYP450 and its implication in the clinical use of antipsychotic drugs. Clin Exp Pharmacol, 2015; 5(3):110. doi: 10.4172/2161-1459.1000176.

9. Gallego JA, Bonetti J, Zhang J, Kane JM, Correll CU. Prevalence and correlates of antipsychotic polypahramacy: A sytemtic review and meta-regression of global and regional trends from the 1970 s to 2009 . Schizophr Res. 2012;138(1):18-28. doi: 10.1016/j.schres.2012.03.018.

10. Ray WA, Chung CP, Murray KT, Hall K, Stein CM. Atypical antipsychotic drugs and the risk of sudden cardiac death. New England Journal Med. 2009;360(3):22535. doi: 10.1056/NEJMoa0806994

11. Kopecek M, Potmesil P. How long does the pharmacokinetic interaction between carbamazepin and quetiapin last after carbamazepin withdrawl?. Neuro Endocrinol Lett. 2017;38(7):475-8.

12. Jain T, Bhandari A, Ram V, Parakh M, Wal $P$, dan Nagappa NA. Drug interactions and adverse drug reactions in hospitalized psychiatric patients a critical element in providing safe medication use [Diunduh pada: 1 Februari 2018]. Tersedia dari: ww w.gjpsy.uni-goettingen.de/gjp-article-jai n2.pdf

13. Granas AG, Berg C, Hjellvik V, Haukereid C, Kronstad A, Blix HS, et al. Evaluating categorisation relevace of drug related problems in medication reviews. Pharm World Sci. 2010;32(3):394-403. doi: 10. 1007/s11096-010-9385-x.

14. Patel PS, Rana DA, Suthar JV, Maholtra SD, Patel VJ. A study potential adverse drug-drug interaction among prescribed drugs in medicine outpatient departement of tertiary care teaching hospital. J Basic 
Clin Pharm. 2014;5(2):44-8. doi: 10.4103 /0976-0105.134983.

15. Bucşa C, Farcaş A, Cazacu I, Leucuta D, Achimas-Cadariu A, Mogosan C. How many potential drug-drug interactions cause adverse drug reactions in hospitalized patients? Eur J Intern Med. 2013;24(1):2733. doi: 10.1016/j.ejim.2012.09.011.

16. Mirosevic SN, Macolic SV, Mucalo I, Krnic D, Bozina N, Tomic S. Adverse drug reaction caused by drug-drug interactions reported to Croatian Agency for Medicinal Products and Medical Devices: A retrospective observational study. Croat Med J. 2011;52(5):604-14. doi: 10.3325 cmj.2011.52.604

17. McCann TV, Boardman G, Clark E, Lu S. Risk profiles for non-adherence to antipsychotic medications. J Psychiatr Ment Health Nurs. 2008;15(8):622-9. doi: 10.1111/j.1365-2850.2008.01277.x.

18. Gibson S, Brand SL, Burt S, Boden ZVR, Benson O. Understanding treatment nonadherence in schizophrenia and bipolar disorder: A survey of that service users do and why. BMC Psychiatry. 2013;13:153. doi: 10.1186/1471-244X-13-153

19. Barkhof E, Meijer CJ, de Sonneville LM, Linszen DH, de Haan L. Interventions to improve adherence to antipsychotic medication in patients with schizophrenia-A review of the past decade. Eur Psychiatry. 2012;27(1):9-18. doi: 10.1016/j.eurpsy.2 011.02.005.

20. Ethica T, Teklu A, Ali D, Solomon G, Alemayehu A. Factors associated with medication adherence among patients with schizophrenia in Mekelle, Northern Ethiopia. PLoS One. 2015;10(3): $\mathrm{e} 0120560$. doi: 10.1371/journal.pone.0120560.

21. Dibonaventura M, Gabriel S, Dupclay L, Gupta S, Kim E. A patient perspective of the impact of medication side effects on adherence: Results of a cross-sectional nationwide survey of patients with schizophrenia. BMC Psychiatry. 2012;12 (1):20. doi: 10.1186/1471-244X-12-20.

22. Nabovati E, Vakili-Arki H, Taherzadeh Z, Hasibian MR, Abu-Hanna A, Eslami S. Drug-drug interaction in inpatient and outpatient settings in Iran: A systematic review of the literature. Daru. 2014;22(1): 52. doi: 10.1186/2008-2231-22-52.

23. Mateti UV, Lalwani T, Nagappa AN, Bhandary PV, Verupaksha D, Balkrishnan R. Assessment of drug-related problem in depressive patient. Perspect Clin Res. 2015;6(1):58-61. doi: 10.4103/2229-348 5.148820

24. Tesfaye ZT, Nedi T. Potential drug-drug interaction in inpatients treated at the internal medicine ward of Tikur Anbessa Specialized Hospital. Drug Healthc Patient Saf. 2017;9:71-6. doi: 10.2147/DHPSS1 26336.

25. Medscape. Drug interaction checker [Diakses pada: 1 Februari 2018]. Tersedia dari: http://reference.medscape.com/drug -interactionchecker

26. Rios-Morales O, Jasso-Gutierrez L, ReyesLopes A, Garduno-Espinosa, MunozHernandez O. Potential drug-drug interaction and their risk factors in pediatric patient admitted to the emergency department of tertiary care hospital in Mexico. PLoS One. 2018;13(1):e0190882. doi: 10.1371/ journal.pone.0190882.

27. Ocaña-Zurita MC, Juárez-Rojop IE, Genis A, Tovilla-Zárate CA, GonzálezCastro TB, Lilia López-Narváez M, et al. Potential drug-drug interaction in Mexican patients with schizophrenia. Int J Psychiatry Clin Pract. 2016;20(4):249-53. doi: 10.1080/13651501.2016.1213854.

28. Berman BD. Neuroleptic malignant syndrome: A review for neurohospitalists. Neurohospitalist. 2011;1(1):41-7. doi: 10. 1177/1941875210386491.

29. Divac N, Prostran M, Jakovcevski I, Cerovac N. Second generation antipsychotics and 
extrapyramidal adverse effect. Biomed Res Int. 2014;2014:656370. doi: 10.1155/201 $4 / 656370$

30. Elliott A, Mørk TJ, Højlund M, Christensen T, Jeppesen R, Madsen N, et al. QTc interval in patients with schizophrenia receiving antipsychotic treatment as monotherapy or polypharmacy. CNS Spectr. 2018;23(4):278-83. doi: 10.1017/ S1092852917000402.

31. Wiśniowska B, Tylutki Z, Wyszogrodzka G, Polak S. Drug-drug interaction and QTc prolongation as a commonly assessed cardiact effect-comprehensive overview of clinical trials. BMC Pharmacol Toxicol. 2016;17:12. doi: 10.1186/s40360-016-00 53-1.

32. Cohagan B, Brandis D. Torsade de Pointes [Diakses pada: 1 Februari 2018]. Tersedia dari: https://www.ncbi.nlm.nih. gov/books/NBK459388/

33. Khasawneh FT, Shankar GS. Minimizing cardiovascular adverse effect of antipsychotic drugs in patients with schizophrenia. Cardiol Res Pract. 2014;2014:273060. doi: 10.115 5/2014/273060

34. Takeuchi H, Suzuki T, Remington G, Uchida H. Antipsychotic polypharmacy and corrected QT interval: A systematic review. Can J Psychiatry. 2015;60(5):21522. doi: $10.1177 / 070674371506000503$

35. Correl CU, Federickson AM, Figen V, Ginn-Scott EJ, Pantaleon Moya R, Kane JM, et al. The QTc interval and its dispersion patients receiving two antypical antipsychotic. Eur Arch Psychiatry Clin Neurosci. 2009;259(1):23-7. doi: 10.100 7/s00406-008-0829-4.

36. De Hert M, Dockx L, Bernagie C, Peuskens B, Sweers K, Leucht S, et al. Prevalence and severity of antipsychotic related constipation in patients with schizophrenia: A retrospective descriptive study. BMC Gastroenterol. 2011;11:17. doi: 10.1186/1471-230X-11-17

37. Hefner G, Unterecker S, Ben-Omar N, Wolf M, Falter T, Hiemke C, et al. Prevalence and type of potential pharmacokinetic drug-drug interaction in old aged psychiatric patients. Contemp Behav Helath Care. 2015;1(1):3-10 . doi: 10.15761/CBHC. 1000103

38. Muench J, Hamer AM. Adverse effect of antipshychotic medication. Am Fam Pshysician. 2010;81(5):617-22.

39. Baxter K, Stockley IH. Stockley's drug interaction: A source book of interaction, their mechanism, clinical importance and management. London: Pharmaceutical Press; 2009.

40. Ogino S, Miyamoto S, Miyake $\mathrm{N}$, Yamaguchi N. Benefits and limits of anticholinergic use in schizophrenia: Focusing on its effect on cognitive function. Psychiatry Clin Neurosci. 2014;68(1):3749. doi: 10.1111/pcn.12088.

41. Al-Ramahi R, Raddad AR, Rashed AO, Bsharat A, Abu-Ghazaleh D, Yasin E, et al. Evaluation of potential drug-drug interaction among Palestinian hemodialysis patient. BMC Nephrol, 2016;17:96, doi: 10. 1186/s12882-016-0317-4

42. Mojtabai R, Olfson M, Sampson NA, Jin R, Druss B, Wang PS, et al. Barriers to mental health treatment: Result from National Comorbidity Survey Replication. Psychol Med. 2011;41(8):1751-61. doi: 10.1017/S0033291710002291.

43. Längle G, Steinert T, Weiser P, Schepp W, Jaeger S, Pfiffner C, et al. Effect of polypharmacy on outcome in patient with schizophrenia in routine psychitaric treatment. Acta Psychiatr Scand. 2012; 125(5):372-81. doi: 10.1111/j.1600-0447 .2012.01835.x.

(C) 2018 Ramdini et al. The full terms of this license incorporate the Creative Common Attribution-Non Commercial License (https:// creativecommons.org/licenses/by-nc/4.0/). By accessing the work you hereby accept the terms. Non-commercial use of the work are permitted without any further permission, provided the work is properly attributed. 